

\title{
Elite Fragmentation and Oligarchic Implosion in Nigeria's Democratic Space: A Mere Stopgap or An Impetus to People's Emancipation?
}

\author{
BY MIKe, OMILUSI PH.D \\ Department of Political Science \\ Ekiti State University, Ado-Ekiti, Nigeria
}

\begin{abstract}
The Nigerian political class operates within convenient and exclusive networks that support a core political composition, that itself is predatory, authoritarian and disconnected from society. Since democratization began in 1988, political competition has intensified, but bureaucracies have remained only moderately effective and political parties and civil society have shown continuing weakness while the elite continually holds the polity by the jugular by way of power contestation and domination. While successive political leaders are unable to offer even the most basic services to the people, more than ever before, it appears the mass public only represents a legitimizing tool for electoral indiscretions. However, the present elite fragmentation (as manifested in crises among agencies and cabals in the executive, the antagonistic dispositions among leaderships of the three arms of government and ruling-opposition parties confrontations) in Nigeria, though at face value, may illustrate some implications of Elite Cartel corruption, and portends some dangers for the fragile political system in the country, it may also serve some unintended purposes which this study seeks to unravel. These developments, combined with deep divisions within the country's elite, may have reinforced the fragility of the nation's democracy and governance neglect to the detriment of the poor. If elite power and roles, despite structural differentiation, have long endured by recurring and extending through time and space without producing meaningful social change, can the present internal wrangling signify a weak point to be explored by the disenchanted mass of the people? Can the Nigerian elites become victims of their own creation - poor governance- or the oligarchic
\end{abstract}


implosion is just a passing phase that will fade away with possible future mutual compromise? Adopting the Weberian rational approaches to elite formation and attitudes, this study examines the capacity of the ruling minorities to form cohesive power actors, that is, to act in a solidary, coherent and deliberate manner in contradistinction to the mass resentment among the populace, particularly in the face of elite fragmentation.

Key Words: Elite, Democratic Space, Fragmentation, Implosion, Emancipation

\section{Introduction and Background to the Study}

One characteristic of political life in postcolonial Africa is the weak sense of, and commitment to the common good or public interest. This is manifested in the way public resources are privatized, political power abused, and the general disregard for legal restraints to the exercise of power which undermine political and public institutions (Aiyede, 2013). Nigeria's crisis of governance is conspicuous. The ruling elites and the public institutions have not provided essential collective goods, such as physical infrastructure, rule of law, or legitimate symbols of state authority and political community. One of the most contentious problems is democracy (Lewis, 2006:89). Democracy is widely acknowledged as the best form of government and Nigeria, after decades of bitter experience with military dictatorship, embraced democracy in 1999. The process has, however, proven to be a hard sell for the people in power, the opposition and the society at large. The major challenges facing democracy in Nigeria include the structure of the country itself and the haphazard procedure for holding those in power accountable to the people. Owing to the country's centre-heavy federal system, formulating and implementing solutions to the plethora of challenges have been daunting. Politicians approach the acquisition of power cynically, harping on the deficiencies of incumbent government but once empowered, they strive mightily to sustain the deplorable status quo they had railed against while in opposition. Thus, it has always been struggle for power among both the ruling class and the elite outside power with little or no consideration for governance. Little wonder, there is overwhelming evidence that the country has a good governance deficit.

The historian sees all this clearly, as do the political scientist and the contemporary historian - the journalist - who is thought of as a member of the Fourth Estate of the realm. All have, however, been unable to proffer an acceptable model for how public discourse could be deployed to advance good governance. 
As aptly canvassed by Pearse Doherty, political culture will change only when politics changes. "For far too long, this state has been governed in the interest of the few. The disadvantaged and vulnerable have, at best, seen a blind eye turned towards their needs". Nigerians, since political independence, have been governed by mostly circumstantial/accidental leaders-a recycled section of the military and political elites- whose knowledge of governance and visions for a great country were substantially limited and often tangential to aspirations for collective/corporate progress.

Since 1999, when the military handed over power to elected civilians, Nigeria's fledgling democracy has remained hotly contested and unstable (Tar and Shettima, 2010:143). However, economic malaise, weak governance, and communal polarization has had a profound social dilemma at the heart of Nigeria's political economy (Lewis, 2006:94). Trust and confidence in the political system have been eroded as a consequence of the perceived mismanagement of the economy, public services and state finances by successive administrations. In spite of this obvious disaffection in the polity, the system has been relatively stable and electoral cycles consistent. Thus, it is believed that what keeps a weakly institutionalized polity stable, according to Bedasso (2015:367), is the presence of a dominant coalition. On the other hands, what keeps a dominant coalition stable, in turn, is the existence of an intra-elite pact, enforced through the threat of 'mutually assured destruction'.

Nigeria's political class is generally fragmented and contentious, its executive is imperious and arbitrary, and its institutions are largely feeble and dysfunctional (USAID, 2006:42). In practice, members of the political oligarchy switch political parties, form new ones, or change party affiliations according to shifting opportunities to gain access to petro-rents and political privileges regardless of professed political principles, or regional or ethnic affiliations (USAID, 2006:15). The relevance of an analytical investigation of the elite fragmentation finds relevance in the importance ascribed to their modes of composition, operation and their ability to present themselves as legitimate representatives of the larger society as a whole (CODESRIA, 2003).

This article not only makes a conceptual and empirical contribution to the study of elite fragmentation and oligarchic implosion, but also contributes to literature on elite-masses dichotomy and power domination. It argues that in the context of Africa's political development and specifically, Nigeria's democratic space, the manifestation of elite fragmentation as observable in the current political dispensation, delicately portends a two-pronged variable. One, the trust that forms 
the basis of the cohesive elite is eroded and thus the polity stands to benefit from its current fragmentation. Two, the inherent fragmentation presents a usually temporary measure (stopgap) that paves way for other forms of realignment/patronage and absorption of aggrieved factions of the political elite in due course.

\section{Power, Elite Formation and Fragmentation: A Theoretical Framework}

Political science, according to Francis (2011), is fundamentally about power. It is about investigations into the exercise of power in a variety of micro-settings; these investigations are a primary way through which political scientists recognise and define power. Thus, power is not independent of its object. Instead, studies of the way in which power is exercised, accumulated and tempered by a multiplicity of actors in a variety of institutional settings provides the substance from which political scientists can define and recognise the very nature of power. Central to these investigations of power are agents that define and bring about change. Without agents, power does not exist. These agents are individuals or groups who exercise their power within the context of their environment, often empowered to act within it but constrained by its framework (Francis, 2011).

The modern state, for practical purposes, consists of a relatively small number of persons who issue and execute orders which affect a larger number in whom they are themselves included; and it is the essence of its character that, within its allotted territory, all citizens are legally bound by those orders (Laski, 1982). The debate on elites and their role in various spheres including the socio-economic and political spheres, has enjoyed wide contributions by several scholars. Chief among these is the Marx's classic theorising of elites as those controlling the state apparatus due to the ownership or control of the means of production and Amsden (2010 cited in Ikpe, 2013) who simply describes the elites as those deriving status from their relationship to physical and human capital. In this regard, a valuable conceptualization of elites in the global space becomes handy. An instructive one is Leslie Sklair (Sprague, 2009:500 cited in Ikpe, 2013) who postulates about the existence of a transnational capitalist class in most political setups. This class comprises: those who own and/or control major transnational corporations, globalizing bureaucrats and politicians, globalizing professionals, globalizing merchants and the media. 
The elite theory was first developed by two Italian Sociologists namely: Vilfredo Pareto (1968) and Gaetano Mosca (1939). The earlier versions of the theory emphasized personal attributes of leaders, which aided their hold or dominance in power positions. Later versions dwelt more on the institutional framework of society (Haralambos, 1999: 107). Pareto, Mosca, Michels, Mills and Hunter have in different ways contended in their theory of the elite that leadership issues in societies do not thrive on pluralism, but more importantly that the stratification paradigm holds the key to harmony within societies. Current elite theory defines 'elites' as actors controlling resources, occupying key positions and relating through power networks (Yamokoski and Dubrow, 2008). Higley and Burton (2006) define elites as 'persons who are able, by virtue of their strategic positions in powerful organizations and movements, to affect political outcomes regularly and substantially'.

As rightly observed by Mosca (1939), in all societies, two classes of people exist- the class that rules and the class that is ruled. According to Mosca cited in (Varma, 1999:144-145), those who get to the top are known as the elites. Similarly, Pareto portrayed all societies as containing two analytic and interacting categories: largely powerless masses and powerful elites, with the latter sub-divided into 'governing' and 'non-governing' elites. Historically, governing elites were hereditary aristocracies anchored in the most gifted and talented - the qualitatively superior elite of a society - and in socially delineated monopolies of power and privilege (Lenski 1966:219-42). The special features ascribed to the elite whether in the governing category or not, makes any member of the elite class, a superior class in any society (Odubajo and Alabi, 2014). In modern societies however, intensified elite circulation and electoral democracy undermine hereditary aristocracies. Modern governing elites, though still socially selective in composition, contain persons and groups recruited from a variety of classes and strata, with privileged bourgeois origins being most prominent.

Pareto conceived of 'governing classes' - as complex aggregations of powerful political, economic and social groups, the inner leaderships of which are located in governments. In Pareto's usage, governing elites encompass opposing parties and allies rotating in and out of government offices and squabbling endlessly over policy matters. But these rotations and squabbles do not alter basic psychosocial propensities and governing styles. Elite members are disposed to combine the two modes of political rule, force and persuasion, but over time they, and especially their leaders, come to rely primarily on one mode, one style of governance (Femia 2006:70). 
Mosca's (1939) explanation is not completely different; he also divides society into the ruling class and the non-ruling class. The ruling/political class is the elites and the sub-elites. The sub-elite in this context refers to technocrats, managers and civil-servants, who are way above the critical mass of the people in terms of access to opportunities from the State. In the ruling and non-ruling class analogy, the elite is presumed to be highly organized while the direct opposite holds for the masses, thus limiting the latter's ability to contest governing processes with the former. The ruling class determines the prevailing political and social forces of their epochs because ideas and institutions are created to suit their purposes, such that they dominate structures and values.

\section{Nature and Characteristics of Elite Formation/Domination in Nigeria's Governance Space}

Africa's entrenched elites, by virtue of their economic and political power, have always influenced public policies and decisions made by them in order to consolidate their control over state affairs at the expense of the people they govern (Baba, 2014). Thus, since independence, politics in many African countries have been constructed as an exclusive domain of elderly and middle-aged men, the majority of whom have accumulated massive wealth, both through corrupt means and opportunistic investment, which they use to fund their political careers. They are a product of a targeted western education, the so-called strategic 'modelschools' built by the British colonial masters to produce Nigerian politicians, bureaucrats and military men (Tar and Shettima, 2010:137-138). The civilizing agenda of the British empire implied the nurturing of a new worldview in the realms of culture, social values, religion and politics in the conquered territories. Indeed, it succeeded to a remarkable extent. As western education became the determining index for participation in public service, recruitment into British colonial bureaucratic institutions was determined by a seemingly sufficient mastery of British middle class etiquette (Ugor, 2005).

Nigeria is a federation with three tiers of government: federal, 36 state governments and 774 local government areas. Each tier has three arms of government: the executive, parliament and the judiciary. At the federal level, a democratically elected president forms a cabinet to administer the country. Nigeria is the most populous African country, with an estimated 182 million in 2015 (World Population Prospects 2015:21) and one of the world's most ethnically 
diverse societies, being made up of over 250 ethno-linguistic groups. Nigeria is deeply divided by regional, religious, ethnic, economic and political rifts, and these have been used and abused in local and national politics.

One of the main research interests in elite literature concerns the relationship between elites and democratic/non-democratic outcomes. While giving an insight into the pre-independence elite formation in Nigeria, Graf (1983) contends that embryonic Nigerian elites, despite their ethnic, political, religious and sectoral differences, had, and still have, high incomes, westernised life styles, advanced education, special privileges such as private schools and trips abroad, and enhanced life prospects; and possession or enjoyment of these things is what distinguishes them from the masses.

The Nigerian oligarchs are members of the fused elite, and in particular, those with several sources of power: military position (present or former), high political and administrative office (elected or nominated), senior positions in the ruling party, and a private business fortune (Amundsen, 2012). The governing elite in Nigeria, deriving from their social characteristics and privileges of office, operate as a formidable team against the mass (people) who are encumbered by daily pressure for sustenance and necessities of life. The manipulative tendencies and tool by the elite inhibit any genuine effort to advance common cause in form of qualitative education, shelter, basic infrastructure and other social amenities as deliverables of democratic governance (Ibietan and Ajayi, 2015). Thus, this social group is characterised by the imperatives of rent seeking and aspires to manipulate the machinery of state in a bid to fulfil egocentric class and group interests (Anugwom, 2011). The political elites exploit disorder and exclusive access to critical information to maintain control over their clients (Osei, 2015). Unfortunately, the state-centrism of most African societies has made the bulk of the people too dependent on the state, and therefore on whoever controls the machinery of the state. In many cases, such persons have exhibited some of the worst tendencies in human nature (Ujomu, 2008).

Nigeria's elite formation, as explained by Amundsen (2012:3), has three characteristics: its establishment through a fusion of elites (with the military dominating), its consolidation through various mechanisms of power diversification (with the conversion of political power into economic power as the basis), and its aggrandisement through various mechanisms of economic extraction (where the usurpation of oil wealth is pivotal). Corruption and the embezzlement of public funds by the political class were the usual excuses by the military for the 
coups which truncated democratic governance in Nigeria at various times. This categorization of politicians as very corrupt was reinforced over time by the reckless lifestyles of elected and appointed public officers (Olorunmola, 2016). Amundsen (2012:3) posits that:

\footnotetext{
The ruling elite of Nigeria was established through what has been called a "fusion of elites", which is relatively similar to the pattern in other African countries. The point is that different elite segments, such as traditional and religious leaders, the nationalists of the independence era, and the upper echelons of the state bureaucracy and the military, have amalgamated into a new ruling elite, primarily based on state power
}

Political power in Nigeria, according to Cooper-Knock (2012), can have many faces. Many operate within the confines of the state, either in its public centre or in its shadowy borderlands. But the state is by no means the exclusive space where political influence is created and exercised. Religious leaders, businessmen, traditional rulers, ethnic community representatives, and neighbourhood elders are all political authorities in their own right. Their power may, in some cases, derive from their connections with the state; but more often than not, these leaders also have access to 'their own', unique sources of political authority (Cooper-Knock, 2012).

The Nigerian political elites, who inherited the powers of the colonialists at independence in 1960, continued this manipulation of ethnic differences for their own selfish interests. In the process, they succeeded in creating the false impression that various politicians and political parties were champions of the interests of the ethnic formations for which they spoke, and that the struggles of these parties for political dominance represented the struggles of their various ethnic groups for ascendance in society. They covertly and even openly used emotive ethnic symbols and played on negative feelings arising from alleged ethnic conflicts of interest, as a means of mobilising mass support for their own personal interests (IDEA, 2001:93). Many political elites dispense public and private resources and services through patronage networks that perpetuate political exclusion. The "winner-takes-all" style of politics raises the stakes and encourages politicians to exploit ethnic, religious and regional identities to achieve political office and power (NDI, 2015).

\section{Buhari Administration and Manifestation of Elite Fragmentation: Nature, Nuances and Dynamics}

As good governance continues to be found lacking by the majority of Nigerians who live without access to basic public services (USAID, 2006:v), and the failure of the ruling class to address deepening frustrations and hardships has 
fuelled popular discontent across the states of the federation since the emergence of civil rule in 1999. As could be deduced from the foregoing, Nigeria has experienced profound, dramatic and sometimes baffling changes which have become a major feature of its development during the past decade. These changes have been driven by the struggle for the control of state power. As a matter of fact, the governing elite in Nigeria deriving from their social characteristics and privileges of office operate as a formidable team against the mass (people) who are encumbered by daily pressure for sustenance and necessities of life. More worrisome is the absence of an elite consensus on the foundational principles and rules by which the country would be governed and the dividends of independence delivered to the people. Ironically, such consensus is not found wanting when it comes to power sharing/resource allocation among themselves. This study will focus on seven major identifiable areas that elite fragmentation is conspicuous for further analysis.

\section{A. Parliament-Executive Avoidable Frictions}

Since its historic victory in 2015 , the party has been grappling with one crisis or the other with the most challenging being the emergence of a set of leaders of the bi-cameral National Assembly the party did not endorse (Owete, 2016). Lingering political tensions in the aftermath of the elections resulted in crisis at national and state levels. The political crises has stemmed from the competition by factional groups within the ruling All Progressive Congress (APC), which could not reach consensus on key appointments such as leadership of the National Assembly and composition of the federal executive. Apart from the struggle for the control of the leadership of the National Assembly (NASS) by vested interests in the ruling party which controls the two chambers of the NASS, series of upheavals have bedevilled efforts to pass the annual budgets, confirm some appointees of the President in the Senate and get some top officials of the Presidency to answer legitimate summons by the Senate.

The election of Bukola Saraki as the Senate President of the eight national assembly was the first significant flash point in the aftermath of historic victory of the APC in the 2015 general election. The outcome rattled and roughened feathers at the highest hierarchy of the party's leadership structure (Yakubu, 2017). Mr. Saraki's ascension was largely facilitated by senators of the PDP, a party on which back he was governor of Kwara State for eight years and senator for four years. 
Initially, the APC rejected the elections of Saraki as Senate President as well as that of Hon. Yakubu Dogora, who emerged as the Speaker, House of Representatives and vowed to punish its members that were involved in what could be described as a grand conspiracy and inordinate ambition to undermine the party's desire to pick candidates of its choice for the National Assembly topmost positions, the party later changed its mind that it had accepted the outcome of the elections (Kupoluyi, 2015). Although Mr. Dogara enjoys some peace having cooperated with the party to some extent, the same cannot be said of Mr. Saraki, once regarded as the beautiful bride when he alongside 10 other PDP senators defected to the party (Owete, 2016).

Ever since 2015, the battle for supremacy between the elites in the executive and the legislature has divided the Nigeria political system along tribal and religious lines, thereby constituting a log in the wheels of democratic practice and values. Many wonder why a Federal Government whose party has a comfortable control of the two chambers of the National Assembly cannot get anything done without muzzle-flexing. Indeed, the activities at the Senate in the recent past, such as the non-confirmation of the acting Chairman of the Economic and Financial Crime Commission, EFCC, Ibrahim Magu, the stepping down of the confirmation of the 27 commissioners recently appointed for the Independent National Electoral Commission INEC, the Senate/Controller General of Custom face off, the Senate report indicting the Secretary to Government of the Federation SGF and a resolution taken on the floor of the Senate to step down action on all request from the executive arm of government until previous resolutions were implemented, were obvious pointers that all was not well between the two.

In fact, the party caucus in the senate is one of the worst hit organs of the ruling party. For instance, consequent upon the February 2018 amendment made to the electoral act- particularly the re-ordering of election sequence by the parliament, preparatory to the 2019 general elections, the APC senate caucus became further fragmented into what is now known as 'pro-Buhari' and 'anti-Buhari' groups.

As a matter of fact, the setting up of a committee by the President to look into the frosty relationship between the Executive and Legislative arm of government is admittance by the government that a rift exists between the two arms of government. The committee is chaired by the Vice President, Yemi Osinbajo (Oyaregba, 2017). Every previous step taken to patch the fractured relationship ended up creating more cracks, raising fears that creating a seamless relationship between the two arms may be a mission impossible. But, for how long will the 
executive and the legislature work at cross purposes? The unwholesome bickerings between the two arms have benefitted neither of the arms, and those who voted for change, are the collaterals (Ojiabor, 2018).

\section{B. Government Agencies Working at Cross-purposes: The inherent Personality Clashes}

Buhari campaigned on a platform of ending waste and restoring probity, efficiency, and transparency (Ochonu, 2016). It is an open fact that in spite of extant anti-corruption agencies and his seeming commitment to fight the social menace, corrupt practices have remained an albatross in the nation's developmental efforts. While the people wallow in abject poverty and want, members of the political class and their business-class associates bask in stupendous stolen wealth (The Guardian, 2016). In the war against the menace of corruption, the country's elite has learned how to use the complicated legal system, its drawn-out legal processes and overburdened courts to develop successful defences against accusations of corruption or crime.

For a man whose persona was generally hailed as representing the highest degree of discipline, it is an irony that the administration headed by President Muhammadu Buhari is almost everywhere rocked by internal discord, and even among his closest aides, acrimony has turned into an everyday occurrence (Aziken, 2018). And to compound matters, the Presidency and other departments of the Executive in their public communications seem to be working at cross-purposes. Statements are ludicrously issued followed by bovine retractions or elucidations. In most cases, the wrong officials make pronouncements that are secondary to their portfolios or assignations (Wabara, 2017). Similarly, various agencies of government are working at cross purposes, even undermining presidential authority with no one calling anyone to order. In any case, most of them are serving their personal interests as they represent no one but themselves.

For instance, inter-agency rivalry has been a consistent feature of Buhari's graft war. Twice he sent the nomination of Magu as head of the financial crimes commission, known as the EFCC, to lawmakers for approval, and on both occasions they rejected him based on state security police reports of alleged prior wrongdoing. That's left the president's anti-corruption czar in a weakened, acting capacity more than halfway into his tenure (Ibukun and Mbachu, 2017). After Magu was nominated by Buhari as head of the EFCC, the DSS, had as expected with such 
presidential nominations, authored two separate reports that concluded that Mr. Magu was not a fit and proper person to preside over the affairs of the EFCC.

The wars have even sometimes led to armed stand offs between institutions of government as happened last November when agents of the Economic and Financial Crimes Commission, EFCC tried to effect the arrest of the immediate past directors-general of the Department of State Services, DSS, Mr. Ita Ekpeyong and that of the Nigerian Intelligence Agency, NIA, Ambassador Ayodele Oke. The EFCC agents were immediately countered by DSS operatives guarding him. Indeed, a reinforcement of about 30 heavily armed DSS operatives not too long after arrived to fend off the EFCC operatives (Aziken, 2018). Also, there is growing evidence of intense inter-agency rivalry and conflicts within the security sector.

Another engaging public spat was between the minister of state (petroleum) Dr. Ibe Kachikwu and the Group Managing Director, GMD of the Nigerian National Petroleum Corporation, NNPC, Mr. Maikanti Baru over allegations of fraudulent award of contracts and other financial misdeeds. The face-off between both men led to open exchange of missives between the two men and institutions. Both men it subsequently emerged, had been relating as cat and mouse with Baru reportedly refusing to be subservient to Kachikwu, the minister. Baru's strength apparently was the direct access he had as GMD to the president which Kachikwu as the junior minister did not have.

However, none of the wars among Buhari's men has been played over public television as the public spat between the Head of Service, Mrs. Winifred Oyo-Ita, and Chief of Staff to the President, Abba Kyari, on November 1, 2017. The bone of contention was the blame game over the recall of the sacked head of the Pension Task Force, Abdulrasheed Maina. Maina who had been declared wanted over alleged multibillion fraud in the public pension sector was secreted back into the service and paid an estimated N20 million in back pay allegedly on the orders of some members of Buhari's cabinet. Oyo-Ita it was learned had opposed the recall on the claim that Maina had been dismissed by the Jonathan regime.

\section{Former Heads of State and Discontentment with Buhari's Style of Leadership}

There have been increasing criticisms of the government's response to the economic crisis that has caused increase in prices, pay cuts and owed salaries, job 
losses and growing unemployment. While some have rated Buhari fairly well, others think he has been abysmal and that his 'body language' (a term which was generously employed in a variety of situations during the last administration) does not support the much touted change which he promised (Adu, n.d) given the level of disillusionment in the polity three years after. President Buhari came to office on the wave of a "massive popularity that seems to be built on his almost mythical renown for incorruptibility, steadfastness and wilfulness" (Jeyifo, 2018).

In a space of two weeks, two former heads of state - Olusegun Obasanjo and Ibrahim Babangida - made major interventions on the state of the nation. In January 2018, public disenchantment has been articulated by some disappointed advocates of the retired president's return to power in no uncertain terms. The publication of a number of opinions aimed at drawing the President's attention to anomalies and aberrations of prevailing conditions in the land have become a shrill torrent of near abuse. This perception of the climate of public opinion has been exacerbated by the utterances of some senior political figures, who have set the tone of the national conversation (Barrett, 2018).

Thus, ahead of the 2019 general elections, former President Olusegun Obasanjo once again set the Nigerian polity agog with his unexpectedly critical open letter to President Muhammadu Buhari (Odufowokan, 2018) highlighting the government's shortcomings and the need for a third force to replace the already tested two dominant political parties in the country, that is PDP and APC. ). In summary, Obasanjo accuses President Buhari of demonstrating three major weaknesses. The three are 'nepotistic deployment', a coded term for the president's perceived indefensible and appalling lopsided appointment of security chiefs from his own part of the country; a 'poor understanding of the dynamics of internal politics' that has produced division and inequality; and his grating buck-passing that sees him avoiding responsibility for unpleasant happenings (Akinlotan, 2018). Obasanjo berated Buhari for allowing the clashes between herdsmen and farmers to go "sour" and messy saying the endorsement of the President by some governors to seek re-election barely 24 hours after 73 people who were killed by herdsmen in Benue State were given mass burial was "a sad symptom of insensitivity and callousness" (Ibekwe, 2018).

Barely two weeks after a similar advice, ex-Military President, Ibrahim Babangida asked President Muhammadu Buhari not to seek re-election in 2019. He urged Buhari to complete his first term and allow a new generation of leaders to take control of the affairs of the nation (Alli, 2018). In a press statement released by 
Kassim Afegbua, his spokesman, Babangida said it was time to sacrifice "personal ambition" for the "national interest" (Sahara Reporters, 2018). Babangida's controversial letter - "Towards a National Rebirth," touched the same raw nerve. He argued that Buhari had failed to weld a fragile country together and he should pave the way for a "new breed" of young leaders in 2019 (The Punch, 2018). The statement also describes the president as an analogue leader unsuited for modern intricacies and challenges, blames him for allowing bloody clashes to fester everywhere in the country, for sticking to an unproductively reactive style of leadership, and for lacking in capacity, both intellectually and idiosyncratically, to manage people and crises (Akinlotan, 2018).

With the gradual loss of confidence in the political party system and the difficulties, which the President Muhammadu Buhari's administration is facing in moving the county out of its current socio-economic challenges in the last two and half years despite its campaign promises, some stakeholders are of the view that the much anticipated restructuring of the governance system might become the determining factor of who becomes the next president in 2019 (Olumide, 2017). The desired change, as advocated in many quarters (See Ogbonnia, 2018), starts with practice of internal party democracy within the two major parties. A true change must embrace a new breed of leaders, particularly the youths, who have the zeal and the competencies to cope with the demands of the 21st century.

\section{The Presidency and Power Tussle among Kitchen Cabinet Members (a.k.a Cabal)}

There seems to be this group of strong aides of President Buhari who have arrogated presidential powers to themselves and are waxing stronger by the day. In an interview with the British Broadcasting Corporation, BBC, Aisha Buhari, the president's wife confirmed that there was indeed a cabal in the presidency. She inferred that the cabal was only after their selfish interests (Moses, 2017). The president's Chief of Staff, Abba Kyari, a former secretary to the government of the federation, Babachir Lawal, and the president's nephew, Mamman Daura are touted as members of the cabal (Moses, 2017). The Senate President, Bukola Saraki, called it "another government" within the government. In his statement shortly after he was granted bail by the Code of Conduct Tribunal, he said: "What has become clear is that there is now a government within the government of President Buhari, who have seized the apparatus of executive powers to pursue their 
nefarious agenda" (Bakare, 2017). The Presidency had asked Saraki to substantiate his claim like some we want me to provide evidence that there is a cabal in Buhari's administration.

However, the once touted closely knitted Buhari's kitchen cabinet consisting of a web of powerful Northern elements now appears to be crumbling in the face of growing ego and interest conflicts, mutual suspicion as well as mounting allegations of corruption among its members, causing it to split into two strong opposing factions.

How can a Presidency that is supposed to be one indivisible unit be so polarized? How can a government that everyone is fighting or rather working against everyone achieve any tangible goal that would benefit the citizenry? Even among the so-called cabal there seem to be a mind-blowing level of polarization as confirmed by covert campaigns from the seat of government (Izeze ,2017). Too often, needless bickering from his team members dominate the air, thus suggesting far too many personal interests working at cross purposes to the detriment of the President's goal for the country. There is a glaring lack of collaboration and synergy among his team members (Ofili, 2017). Even among the ones the ordinary citizens see as the President's men, every day we hear of dirty infighting, backstabbing and outright mudslinging. Recall that the Secretary to the Government of the Federation (SGF) was informed that he has been suspended by the Presidency, the first question he asked was: "who is the Presidency," thereby indicating a terribly divided Presidency (Izeze, 2017). According to Jibrin (2016) presidential authority is about the power, or rather, the competence to make decisions, give directives and enforce compliance to the said decisions and directives. When a president gives directives and state institutions under his authority take action to nullify the directive, the implication is that they feel no compulsion to obey the president, and that is a bad sign for the exercise of authority.

\section{E. The Southern and Northern Leaders Divide}

Broad differences between North and South are a Nigerian historical, political and religious reality, and, as such, the distinction between the two provides a legitimate analytical lens (Campbell, n.d). However, recently, the debate about restructuring the country which has dominated, more than every other issue, the national discourse, has also pitched the Northern elite against its southern counterparts since the advent of this administration as it has always been. Various 
public opinion leaders, as observed by Itodo (2017), have been expressing varying views about restructuring Nigeria. While some are in support some others are against. There is a lack of consensus on how Nigeria should be restructuredSystematic and periodic constitutional reviews; sovereign national conferences, referenda or dissolution of government with the institution of an interim government are some of the modalities highlighted for a proper restructuring of the country. In fact, one school of thought expresses fear that any attempt to discuss the unity will dismember Nigeria.

In 2017, some even agitated for breakaway and forming of Biafra with Indigenous People of Biafra (IPOB) agitations. The clarion calls for restructuring since 1999 has focused on resource ownership and control, regional or state autonomy, and local initiative for sustainable development. The organisations and individuals involved in the advocacy want political and economic power devolved to the federating units for promote democracy and accountable, responsible leadership.

"Restructuring" has come to represent, in reality an omnibus word for all forms of adjustments, alterations and cosmetic manipulations aimed at changing the formula on the basis of which economic resources and political power are shared or distributed among the Nigerian elite. Each section traditionally defends the area of its comparative advantage at any given time, standing by the status quo when it serves its purposes and asking for "restructuring" when it does not (Sanusi, 1999). The North has long feared domination by the more advanced South, and, hence, was unenthusiastic about independence. Distrust of the South remains widespread, and there is the long standing view that only through political power can the North catch up to, or even hold its own with the South. In general, control of the state has been accomplished through various forms of power sharing (Campbell, n.d).

Leaders from the Southern part of the country and their counterparts from the Middle Belt, insist that Nigeria must be restructured now, just as they demand the implementation of the recommendations of the 2014 National Conference (Adisa, 2017). However, the Northern Senators Forum (NSF) described the matter as ambiguous, even to "proponents, without clear terms and directions on how to go about it" (The Guardian, 2017). Tanko Yakassai (cited in The Guardian, 2017), one of the northern elites posits that: "We are suspicious that the motive is to deprive the north in two important areas - representation at the National Assembly which is on the basis of population, and because there are more states in the north than in the 
south, when it comes to revenue allocation on the basis of equality of states and local governments, the north is bound to benefit more".

\section{F. State Governors- Senators Bickering}

Ahead of the 2019 elections, state governors and senators elected to represent some districts in their various states, are at loggerheads over political ambitions and permutations. These developments have set the political firmament in many states across the country agog with the gladiators and their supporters engaging themselves in deft games of political manoeuvring. In some states like Kaduna, Kogi, Kano and Akwa Ibom, there have been cases of physical clashes between supporters of the combatants leading to destruction of properties and maiming of some supporters (Odufowokan, 2018).

While the causes of the acrimony differ from one state to the other, one thing that is constant in all the affected states remain the determination of the governors to truncate the ambitions of some senators to return to the red chamber for another term of four years. In some states, it is because the senators disagree with the governors over who should be the next governor of their state while in other affected states and senatorial districts, it is because the governors, or their anointed ones, are poised to take over the senators' seats.

In some of the cases, the conflicts are geared towards the 2019 elections. In others, it is simply a battle for supremacy and ego. While lawmakers elected on platforms different from those of the state governors are reasonably expected to challenge the policies of the rival parties, the highlighted APC crises show that it may be worse within the party's own leaders (Busari, 2018).

Political scientists have explained why politics, which is a vocation, has become a career for the 'professional' politicians. While some aspirants perceive their next political office as a call to service to the state, others perceive the corridor of power as an avenue for private accumulation. The latter has however, become a constant feature of the ruling class in Nigeria with a zero-sum game mindset at every level of contestation. 


\section{G. The Ruling Party and Its Aggrieved Members/The Ruling Party and Opposition Movements}

Apparently, the ruling party's strength is also its weakness. Formed in February 2013, the party is the result of an alliance of Nigeria's three biggest opposition parties - the Action Congress of Nigeria $(A C N)$, the Congress for Progressive Change (CPC), the All Nigeria Peoples Party (ANPP) and a faction of the All Progressives Grand Alliance (APGA) - which merged to take on the ruling PDP. Having achieved the purpose for which it was established, the party appeared not to have given adequate thought to what would happen after the election (Oyeyipo, 2017).

The APC is enmeshed in deep internal wrangling in no fewer than 10 states of the federation. The crises, many of which involve state governors and federal lawmakers, erupted few months after the 2015 general elections. The crises are caused by allegations of financial misconduct, anti-party activities, ambitions, maladministration, among others by party faithful. Some of the crises have also led to the suspension or expulsion of key members and officials of the party at the state level. Some of the APC state chapters battling with crisis include Gombe, Plateau, Bauchi, Kaduna, Kogi, Kano, and Ogun.

For instance, in Kano, which is supposed to be the political base of President Buhari, Governor Ganduje is fighting Senator Kwankwaso who not only delivered Kano state one hundred percent to the ruling party in 2015 but came second during the party's presidential primaries. Like Kano, most state branches of the ruling party are in crisis (Mahmood, 2018). The All Progressives Congress (APC) controls 24 states, both Houses of the National Assembly and the presidency, yet the APC appears to be the main opposition against itself on national issues.

There have also been scenarios that give the impression of fissures among the National Working Committee members and some leaders of the APC. This division was well pronounced in September 2016 when the National Leader of the party, Asiwaju Bola Tinubu, called for the removal of Chief John Odigie-Oyegun as the National Chairman of the party (City Mirror, 2017). Also, a former vice president, Atiku Abubakar, once accused Buhari's government which he said he helped into power in 2015 of scheming him out. Abubakar's accusations at the government came the same day Aisha Alhassan (a serving minister), said she would support the former vice president even if Buhari runs for election in 2019. In an interview on the Hausa Service of the Voice of America, VOA, Abubakar said he 
had been side-lined despite his efforts in making sure that the Peoples Democratic Party, PDP, was defeated in 2015 (Oyeyipo, 2017).

Mrs. Buhari who once decided to wade into the crisis rocking the ruling All Progressives Congress (APC), posited that the party internal wrangling was a grave worry for the administration. The first lady said that those behind the crisis felt aggrieved that they laboured for, and helped the President Buhari to power in 2015, but received no compensation. Her remarks came on the heels of an unfolding rift between a former Governor Lagos State and the ruling party's National Leader, Bola Ahmed Tinubu, and the National Chairman of the APC, John Odigie-Oyegun.

From the opposition, the People's Democratic Party (PDP) has also emerged as the arrowhead of a plot to coalesce all opposition parties and groups for the purpose of dislodging the All Progressives Congress (APC) from power in the 2019 elections. Indeed, some founding fathers of the party, under the Movement for a New Political Order, Have defected to the Social Democratic Party (SDP) with a view to "working together to ensure the emergence of a new and credible political order to deepen democracy, good governance and genuine development, with peace, security and social justice" (Abati, 2018).

\section{The Nigerian Realities and the Implications of Elite Fragmentation}

Divided societies are widely assumed to face particularly, serious challenges in holding democratic elections, maintaining political stability, and accommodating rival elites. The composition of the core political executive elite reflects the interests of the few who benefit from the exclusion of the majority of the population. This situation is at odds with the democratic spirit of liberal pluralist assumptions, which reflect equality of participation (Kifordu, 2011). If the cohesion of the political elite, over the years, has always been to the detriment of the mass of the people whom they claim to represent, can its fragmentation be of benefit? And to whose benefits?

According to Burton \& Higley (1998:47), "elites become connected to one another through a web of power and influence networks that facilitate power sharing, they increasingly recognize boundaries and horizontal accountabilities between the organizations and institutions they head; and they come to expect that sanctions will be applied if boundaries and accountabilities are violated". Such interconnectedness/unity has always been strengthened in Nigeria by a bound of 
corrupt practices, bridge-building across the country's geo-political zones and political alignments. Those who get sanctioned for violating "boundaries and horizontal accountabilities" are usually a faction of the elite outside power; who in turn, whips up ethno-religious sentiments to heat up the polity as it is now. The debilitating effects of this on the citizenry and the fragile democratic experiment are immeasurable.

Quite interestingly, the political and economic elites have become victims of the rot they created in the country- bad governance- and this is further accentuated by the lingering elite fragmentation being experienced in the country. The reverberating effects of this development on the polity can be viewed from the lens of political instability, poor service delivery and instigated ethnic and religious conflicts. As posited by Bedasso (2015:381), elite fragmentation and uncertainty could sometimes produce a recipe for stability. While Nigeria's comprehensive approach to democratic planning has enabled elite continuity, it has not enhanced state capacities to deliver good governance to the mass of the people.

Under the prevailing condition of society it seems only prudent that Nigerian patronage seeking politicians exercise some restraint on their reckless contestations over who gets more of the proverbial national cake (Amoda, 2012). Nigeria is presently in a social condition of anarchy and Nigeria's elite are attempting to continue with the only game of politics they are proficient in, the game of patronage politics. The holder of power rules with impunity, and the benefits of power accrue to a narrow fraction of elites while large swathes of society wallow in object poverty, marginalisation repression and hopelessness (Tar \& Shettima, 2010). In other words, while life is made difficult for the Nigerian masses, consequent of the elite-misrule, the elites are rather making progress with their lives. This may have reinforced Coleman's (1986: 62) submission:

For the Nigerian political elite, politics involves not the conciliation of competing demands arising from an examination of the various alternatives entailed by any course of political action, but the extraction of resources which can be used to satisfy elite demands and to buy political support. The political relationship is essentially a relation between patrons and clients in which the patron survives only to the extent that he satisfies the demands of his clients, and clients give their support insofar as the patron 'delivers the goods'.

Tragically, the Nigerian multitude and suffering masses who are expected to intervene very decisively in this hegemonic war of the ruling class, have been so hobbled by poverty and misery that they have resorted to their own Ponzi scheme to get rich quickly (Alamu, 2016). In 2016, OXFAM reported that the total wealth owned by the five richest Nigerians can lift Nigerians living below the poverty line 
at $\$ 1.90$ out of poverty for one year. This degree of extreme poverty coupled with rising unemployment creates opportunities for social disharmony and instability (Itodo, 2017). In a situation of deepening misery and hunger, the ordinary people will be vulnerable to economic miracle workers and religious Rasputins. In a way, this development is good for the nation, for, it forces us back to the fundamental issue, which is the unresolved national question. It has been said that history is something that hurts and that which will not ignore us however much we ignore it (Alamu, 2016).

Ninalowo (1999) argues that for the society not to be propelled toward selfannihilation through intra-class and inter-class struggle over mutually contradictory interests, it becomes historically imperative on the state to bring about orderliness via the abiding interests of legitimation. In Nigeria, dissatisfaction with government performance, dashed hopes, expectations and frustration has contributed in no small measure to the crises of legitimacy. Elitism as a democratic perspective, as alluded to in this essay, unfolds the understanding that representative democracy is a function of the dictates and manipulations of the elites based on class organization and acquisition of political skill (Olaniyi, 1997; Varma, 2001).

Nigeria is a state with endless list of absurdities. It is only in Nigeria that brazen political elites blamed political leadership (themselves) for the development deficits of Nigeria, and yet were unwilling to throw in the towel, or take such necessary drastic measures that would address the deficits (Odeyemi, 2013). The elites' self-blame could be considered a gimmick to pretentiously assuage the hoodwinked masses, designed also to make the latter think that the former is troubled and genuinely worried about their plight, whereas, nothing concrete is done to correct the ills (Odeyemi, 2013). The Nigerian experience may have fitted well into the pattern described by the literature on elite settlements. As being observed now, the frequency of elite alignment and realignment across political parties in the preparations for the 2019 general elections has been on the rise particularly among those whose interests are not protected by the APC government.

Just as Mosca (1939) and Pareto (1968) drew attention to the linkages between elite unity or division and the prospects of building democracy to suggest that stable democratic regimes are fostered by unity within the elites, the fragmentation among the ruling elites in Nigeria may therefore portend crisis in the polity. Apparently, a consensually unified national elite on issues of governance- 
reflecting social welfare policy, rule of law, justice- have not been on the political radar since the beginning of the fourth republic. It may still not emerge soonest as many of the political grouping- that circumstantially harbour the elites- have degenerated into neo-patrimonial cartels of primitive looting and state banditry.

\section{Conclusion}

The country presently deserves meaningful political reform proposals that must be based on the principles of sovereignty, democracy, accountability, transparency, national unity, equality, the empowerment of local communities and the creation of a political system where citizens come first (Doherty, 2017). What Nigeria needs, according to Agbakoba (cited in Daily Trust, 2017) is a new deal, and the present political elite cannot deliver because of entrenched personal interest. Going forward, the civil society needs to wrest power from this ruling political elite to achieve a new system that is inclusive and works for all and not a few. As posited by Fawole (2018) "we need a serious dialogue on how to totally restructure and repackage the entire architecture of politics and governance to make it address our developmental challenges. As currently configured and being operated, Nigeria is clearly rigged against progress and performance". Also, the monopoly of power by few ruling class should be broken. Political power holding should not be vested with just few ruling elites; rather it should be re-distributed to accommodate all groups or constituents of the Nigerian state. The ordinary Nigerian is far better off with a Nigerian government that is dedicated to pursuing the goal of creating a more just and fairer society for all than relying on political entrepreneurs from regional elites that claim to promote ethnic and regional agendas, when their real goal is self-promotion and aggrandizement.

\section{References}

Abati, Reuben (2018) 2019: PDP plots to unify opposition parties against APC, Available at: http://www.reubenabati.com.ng/index.php/component/k2/item /6429-2019-pdp-plots-to-unify-opposition-parties-against-apc

Adisa, Taiwo (2017) We must restructure Nigeria now, Southern, Middle Belt leaders insist, Nigerian Tribune, July 16 
Adu, Opeyemi (n.d) Is President Buhari Slow or Strategic? Nigerian Monitor, Available at: http://www.nigerianmonitor.com/is-presidentbuhari-slow-or-strategic/

Akinlotan, Idowu (2018) IBB runs with the hare and hunts with the hounds, The Nation, February 11

Akinlotan, Idowu (2018) Obasanjo throws a spanner in the works, The Nation, January 28

Alamu, Tatalo (2016) A Ruling Class tragedy in Nigeria, The Nation, December 18

Alli, Yusuf (2018) IBB to Buhari: Dont contest for another term, The Nation, February 4

Amoda, John (2012) Nigeria elite and the currents of political anarchy, Vanguard, March 6

Tar, Usman A. and Shettim, Abba Gana (2010) Hegemony and subordination: governing class, power politics and electoral democracy in Nigeria, Information, Society and Justice, Volume 3 No. 2, pp 135-149

Amundsen, Inge (2012) Who rules Nigeria? NOREF Report, Available at: https://www.files.ethz.ch/isn/155276/eac00c0675bee0dcdb9cf77e 50b37f68.pdf

Anugwom, E.E. (2011) From Babangida to Obasanjo: The State, rent-seeking behaviour and the realities of privatization in Nigeria, International Journal of Sociology and Anthropology Vol.3(7), pp. 204-216, July

Aziken, Emmanuel (2018) The many wars in Buhari's government, Vanguard, February 3

Baba, Ibrahim (2014) Elites and Exclusive Politics in Sub-Saharan Africa, African Journal of Political Science and International Relations, Vol. 8, No. 8, pp. $271-274$

Bakare, Waheed (2017) Nigeria and the unending cabal stories, New Telegragh, November 4

Barrett, Lindsay (2018) When the urge for change is real, The Sun, January 25 
Bedasso, B.E (2015) Ethnicity, Intra-Elite Differentiation and Political Stability in

Kenya, African Affairs, 114/456, 361-381, doi: 10.1093/afraf/adv020

Busari, Kemi (2018) 2019: Inside the APC Crises: Senators battle state governors Premium Times, January 19

Burton, M. \& Highley, J. (1998) "Political Crises and Elite Settlements" in M. Dogan \& J. Higley (Eds.), Elites, Crises, and the Origins of Regime. Lanham: Rowman \& Littlefield Publishers, Inc

Campbell, John (n.d) Why Nigeria's North South Distinction Is Important, Available at: https://www.huffingtonpost.com/amb-johncampbell/why-nigerias-north-south-_b_817734.html

City Mirror (2017) APC, a House Divided Against Itself, August 4

Coleman, J. (1986), Background to Nationalism. Benin City: Broburg \& Wistrom

Cooper-Knock, S.J. (2012) Fragmented power and Nigerian politics, Available at: http:// democracyinafrica.org/fragmented-power-and-nigerianpolitics/

Council for the Development of Social Science Research in Africa (2003) The African Power Elite: Identity, Domination and Accumulation et accumulation, Available at: http://www.codesria.org/spip.php?article59

Daily Trust (2017) 10 Nigerian Leaders, 10 Ideas About Restructuring, July 9

Doherty, Pearse (2017) Fundamental Change is Possible Where There is Political Will, Available at: http://www.macgillsummerschool.com/fundamental-change-ispossible-where-there-is-political-will/

Fawole, Alade (2018) Shehu Sani's gauntlet! The Nation, March 23

Femia, Joseph V. (2001) Against the Masses. Varieties of Anti-Democratic Thought Since the French Revolution, London, Oxford Univ. Press

Francis, Suzanne (2011) Institutionalizing elites: Political elite formation and change in the KwaZulu-Natal provincial legislature, Afrika-Studiecentrum Series, Available at: 
https://openaccess.leidenuniv.nl/bitstream/handle/1887/18561/ ASC-075287668-3104-01.pdf?sequence $=2$

Graf, William (1983) “African Elite Theories And Nigerian Elite Consolidation: A Political Economic Analysis'In Y. Barongo (Ed) Political Science In Africa (London: Zed) Pp. 189-210.

Higley, John and Burton, Michael (2006) Elite foundations of liberal democracy (Rowman and Littlefield, Lanham, MD, 2006)

Haralambos, M. and Heald, R.M. (1999) Sociology: Themes and Perspectives. (Nineteenth Impression) Oxford: University Press.

Ibekwe, Nicholas (2018) Obasanjo attacks Buhari, asks president not to run in 2019, Premium Times, January 23

Ibietan, J.I and Ajayi, O.O. (2015) The Governing Elite and Democratic Consolidation in Nigeria: An Appraisal of the Fourth Republic, Journal of Human and Social Science Research, Vol. 06 (01), 2015, 014-021

Ibukun, Yinka and Mbachu, Dulue (2017) Security Agency Feuds Threaten Buhari's Graft War in Nigeria, Available at: https://www.bloomberg.com/news/articles/2017-11-29/buhari-sgraft-war-stumbles-as-nigeria-security-agencies-quarrel

IDEA (2001) Democracy in Nigeria, A Publication of International Institute for Democracy and Electoral Assistance (International IDEA)

Ikpe, Eka (2013) Elites and leadership in Africa: Is it enough to be African? Leadership Issues in Africa, No. 2, February

Itodo, Samson (2017) The Restructuring Debate: Serving Nigerian Elite Interest, Premium Times, October 31

Izeze, Ifeanyi (2017) State Of The Nation: The Aisha Buhari Testament And The Leaked Phone Chat, Sahara Reporters, September 19

Jeyifo, Biodun (2018) Plot and plotlessness in the "Buhari script" of politics and history: reflections (1), The Nation, February 11 
Jibrin, Ibrahim (2016) The Magu Affair and the Crumbling of Presidential Authority, Available at: https://omojuwa.com/2016/12/maguaffair-crumbling-presidential-authority-jibrin-ibrahim/

Kifordu, Henry Ani (2011) Political Elite Composition and Democracy in Nigeria, The Open Area Studies Journal, 2011, 4, 16-31

Kupoluyi, Adewale (2015) The NASS Leadership Crisis, http:/ / www.africanexaminer.com/the-nass-leadership-crisis/

Laski, H.J (1982) A Grammar of Politics (7th Impression) London, Allen and Unwin Lenski, Gerhard (1966) Power and Privilege, New York: McGraw-Hill

Lewis, P.M (2006) “The Dysfunctional State of Nigeria”, Short of the Goal: US Policy and Poorly Performing States, Washington DC: Center for Global Development, Pages 83-116

Mahmood, Abba (2018) Is President Buhari Not Aware? Leadership, January 25,

Mosca, G. (1939), The Ruling Class. McGraw-Hill, Inc.

Moses, Joshua Chizurumoke (2017) Two Years On, Nigerians Are Not Convinced About President Buhari's Fight Against Corruption, Available at: http:/ / venturesafrica.com/ what-us-secretary-of-state-visit-africameans-for-us-africa-relations/

NDI (2015) Statement of the National Democratic Institute's International Observer Mission to Nigeria's March 28 Presidential and Legislative Elections, March 30

Ninalowo, Adebayo (1999). "Theoretical underpinnings" in A Ninalowo (ed.) Crisis of legitimation: The State and Vested Interests, Obaroh \& Ogbinaka Pub. (in collaboration with First Academic Pub.)

Ochonu, Moses E. (2016) Bring back corruption: A critique of neoliberal anticorruption rhetoric, The News, September 8

Odofowokan, Dare (2018) Obasanjo 'letter bomb': What can Buhari do? The Nation, January 28 
Odeyemi, Oluwole Jacob (2013) Elite-Priesthood Connivance In Nigeria: implications for security and development, JORIND 11(2) December

Odubajo, Tola and Alabi, Bamidele (2014) The Elite Factor in Nigeria's PoliticalPower Dynamics, Journal of Studies in Social Sciences, Volume 8, Number 1, 2014, 121-139

Odufowokan, Dare (2018) 2019: Fierce battles in the states as senators dare governors, The Nation, March 25

Ofili, Frank (2017) A President and his men, Available at: http:/ / nigeriancanadiannews.ca/a-president-and-his-men/

Ogbonnia, S.K.C 92018) Obasanjo Follows Good Intentions with Bad Actions, Sahara Reporters, February 6

Ojiabor, Onyedi (2016) Cost of unending executive, legislature stand-off, The Nation, March 6

Olaniyi, J.O. (1997). Introduction to contemporary political analysis, Ilorin: Tim-Sal.

Olorunmola, Adebowale (2016) Cost of Politics in Nigeria, Available at: http:/ / www.wfd.org/wp-content/uploads/2016/07/NigeriaCost-of-Politics.pdf

Olumide, Seye (2017) Restructuring as a factor in 2019 elections, The Guardian, December 7

Osei, Anja (2015) Elites and Democracy in Ghana: A Social Network Approach, African Affairs, 114/457, 529-554

Owete, Festus (2016) Analysis: Nigeria's ruling party at war with itself, Premium Times, April 17

Oyaregba, Shaka (2017) Understanding the crux of the executive-legislature face off, Business Day, April 14

Oyeyipo, Shola (2017) APC: A Party at War With Itself, This Day, September 18

Pareto, V. (1935), The Mind and Society. New York: Harcourt, Brace and Co

Sanusi, L. Sanusi (1999) Issues in Restructuring Corporate Nigeria, Being a paper presented at the "National Conference on the 1999 Constitution" 
jointly organised by the Network for justice and the Vision Trust Foundation, at the Arewa House, Kaduna from 11th -12th September, 1999.

Tar, U.A and Shettima, A.G (2010) Hegemony and subordination: governing class, power politics and electoral democracy in Nigeria, Information, Society and Justice, Volume 3 No. 2, July 2010: pp 135-149

The Guardian (2016) Nigeria: As Corruption Fights Back, December 5

The Guardian (2017) Northern leaders list terms for restructuring, want Marshall Plan, December 14

The Punch Editorial (2018) Buhari, your best is not good enough, January 24

Ugor, Paul (2005) “The Developing Underdevelopment": Democracy, New Political Elites and the Emergence of Mountain Tourism in Nigeria. Nebula, Vol. 2. No. 4, Dec/Jan

Ujomu, Philip (2008) Africa's Political Justice Problem and the Politics of Justice in the Development Architecture, This paper was presented to the CODESRIA/APISA/CLACSO South-South International Seminar on Rethinking the International Development Architecture: Perspectives form the South, in Pretoria, South Africa.

USAID (2006) Democracy and Governance Assessment of Nigeria, United States Agency for International Development

Verma, S.P. (1999), Modern Political Theory. Vikas Publishing DVT Ltd. New Delhi. Wabara, Ebere (2017) For President Buhari \& APC, The Sun, September 18

Yakubu, Muhammad (2017) Saraki @ 55 - The Scion of Legislative Regeneration, Leadership, November 19

Yamokoski A and Dubrow JK (2008) How do elites define influence? Personality and respect as sources of social power. Sociological Focus 41(4): 319-36. 


\section{About the author:}

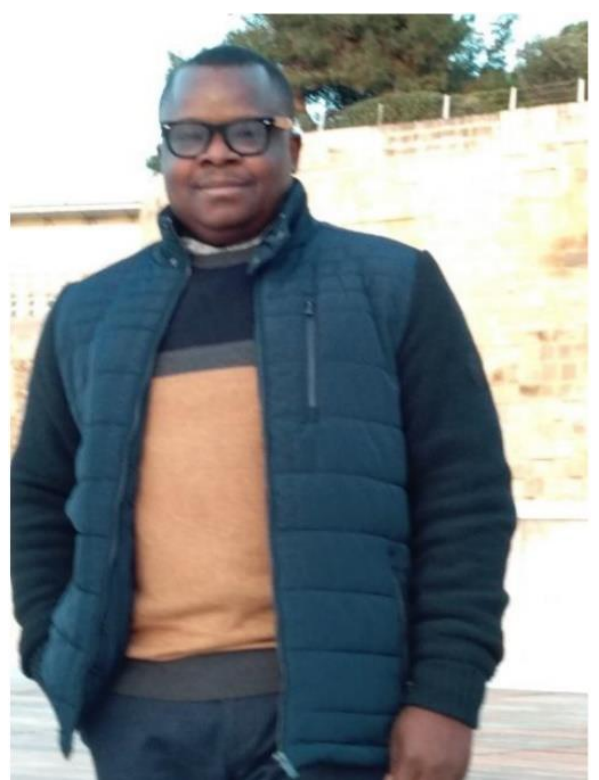

Mike Omilusi studied at Ekiti State University, Nigeria, and received his doctorate in political science in 2014. He has been teaching and researching for over a decade on issues of political sociology, democratization, gender and conflict research in sub-Saharan Africa. Before joining the university's academic staff in 2009, he had worked with civil society organizations in Nigeria for seven years and was awarded the prize for the best democracy monitoring in Nigeria by the Commission for Justice, Development and Peace. $\mathrm{He}$ is known as a researcher, humanitarian volunteer, essayist and advisor to government, civil society groups and international organizations. $\mathrm{He}$ is an active player in the current democratisation process in Nigeria, particularly in the field of civic education and election monitoring. 